\title{
If I knew they were the expression of creativity in people with blindness, I would rate them higher -
} Bias in Evaluating the Work of People with Blindness*

\author{
Magdalena Szubielska \\ The John Paul II Catholic University of Lublin, Poland \\ E-mail address: magdasz@kul.lublin.pl
}

\section{Agnieszka Fudali-Czyż}

The John Paul II Catholic University of Lublin, Poland

E-mail address: agnieszka.fudali.czyz@gmail.com

\section{ARTICLE INFO}

\section{Keywords:}

Empirical aesthetics

Gallery context

The stereotype of disability

Cognitive mastering

Aesthetic Aha

Attributional approach

Creativity

\section{A B S TRACT}

Objective: In our pilot study, we tested to what extent subjective understanding and aesthetic appreciation of embossed drawings were dependent on the information that their creators were people with disability. Method: Our research was carried out in a gallery of contemporary art with 30 adults who were non-experts in the field of visual arts. Subjects were asked to view the current exhibition and then evaluate their subjective understanding and aesthetic appreciation (liking and interest) of 12 embossed drawings on seven-point scales. Results: Participants who were aware that persons with blindness had created the drawings (the informed group) in contrast to those who remained unaware (the uninformed group) declared - both - greater subjective understanding and higher appreciation of the exhibited works. In the informed group ( $N=15)$, in comparison to the uninformed group $(\mathrm{N}=15)$, the correlation between appreciation and subjective understanding of artwork was stronger. Conclusions: We discuss our pattern of results considering the attributional approach to creativity (Kasof, 1995) and the model of a cognitive mastering process of aesthetic experiences (Leder, Belke, Oeberst, \& Augustin, 2004). Our results can be used, among others, by educators working in art galleries and museums.
ISSN: 2354-0036

DOI: $10.1515 /$ ctra-2019-0011

\section{INTRODUCTION}

There continues to be a controversy about whether it is possible to objectively assess artistic creations (Lundy, 2016). A growing body of studies demonstrates that aesthetic experience is a conjoint function of art-object and contextual information toward the art-

\footnotetext{
* The authors would like to thank the contemporary art gallery Galeria Labirynt in Lublin for their cooperation and Aleksandra Gembka and Mateusz Knap for data collection.
} 
object. Contextual information, which changes the aesthetic experience, refers - among others - to the title or description of the work of art (Gerger \& Leder, 2015; Jucker, Barrett, \& Wlodarski, 2014; Leder, Carbon, \& Ripsas, 2006; Millis, 2001; Russell, 2003; Russell \& Milne, 1997; Smith, Bousquet, Chang, \& Smith, 2006; Specht, 2010; Swami, 2013; Szubielska, 2018b; Szubielska, Imbir, \& Szymańska, 2019; Szubielska, Ratomska, Wójtowicz, \& Szymańska, 2018; Szubielska, Wójtowicz, Szymańska, Ratomska, \& Sztorc, 2018).

The issue of bias in assessment has been raised not only in the context of artistic works and creativity but also in the context of the work of students (which, incidentally, may also bear the hallmarks of artistry, e.g., essay writing). A meta-analysis by Malouff and Thorsteinsson (2016) showed that previous research results justify the statement that a bias exists in the subjective grading of student work. Some of the studies included in the meta-analysis reported large effect sizes. Examples of studies that have shown large effect sizes (mean $g=1.10$ ) in terms of bias in assessment are those in which the stereotype of education-related deficiencies ( $g=1.15, N=22$, see Graham \& Dwyer, 1987), attractiveness ( $g=1.12, N=40$, see Landy \& Sigall, 1974), and sex ( $g=1.02, N=44$, see King, 1998) were manipulated.

Various stereotypes activated by information given about an author can influence the assessment of his/her artistic work (Lundy, 2016). The reception of art depends also on knowledge about the artist, specifically: exposure of the artist's name (Lebuda \& Karwowski, 2013; Cleeremans, Ginsburgh, Klein, \& Noury, 2016), whether he or she is famous (Mastandrea \& Crano, 2019) and the number of authors of the artwork (Smith \& Newman, 2014). For example, in the study by Lebuda and Karwowski (2013), nonexperts assessed the creativity of products from the fields of art and science. The results of the study showed that creativity assessment is higher when the artwork is: authored by a person with a unique name (in contrast to common name) or authored by a man (compared to a woman) (for bias in creativity assessment see also Kaufman, Baer, Agars, \& Loomis, 2010).

Non-experts especially, may use heuristic cues based on knowledge about the artist to denote the value of an artwork. Non-experts show greater appreciation for individual artworks than collective ones (Smith \& Newman, 2014); artworks bearing the author's name rather than unidentified pieces of art (Cleeremans et al., 2016); artworks of a famous rather than non-famous author (Mastandrea \& Crano, 2019).

It has also been demonstrated that other types of information about the author, for example, indication of a disability, enhances the aesthetic evaluation of both art nonexperts and art experts (Niestorowicz, 2017; Szubielska, Bałaj, \& Fudali-Czyż, 2012). Art experts (students of art faculties) who knew that people with simultaneous deafness and 
blindness made sculptures assessed those sculptures as more creative, original, innovative and also more exciting than unaware experts. At the same time, deformations in the sculptures were more often considered to be an intended artistic effect when there was no knowledge that the creators of the artwork were deaf and blind (Niestorowicz, 2017). In a study of non-professional art receipients (psychology students), the evaluation of a photo (especially with a blur effect) was significantly higher if the recipients knew that the author was a person with intellectual disability than if they were unaware (Szubielska et al., 2012).

The effect of awareness of artists' disability has so far been explained as the result of activation of stereotypical thinking that brings about the assumption that people with impairment cannot create artwork, which is as good as that of people without impairment (Niestorowicz, 2017; Szubielska et al., 2012). Heider's attribution theory mechanisms as explained in Kasof's commentaries (1995) assumed that bias in creativity assessment changes all aspects associated with creativity. The activation of stereotypical thinking by providing information on the fact that the creators were people with visual impairments may cause bias in terms of an inflated assessment of the work.

But higher appreciation of the artwork of an artist with impairment can also result from the fact that information about disability supports the cognitive mastering process in the reception of artwork. A model of cognitive processing of aesthetic experiences (Leder, Belke, Oeberst, \& Augustin, 2004) assumes that cognitive mastering is the last of four stages (after perceptual analyses, implicit memory integration, explicit classification) which precede the aesthetic evaluation of the artwork. The model (Leder et al., 2004) predicts that successful or unsuccessful cognitive mastering, related to self-rewarding experience, impacts aesthetic judgment. Additional information about artwork (e.g., on authors with a disability) should enhance the cognitive processing of artwork (see Belke, Leder, \& Augustin, 2006), ending with growth of aesthetic appreciation and understanding. In the case of the work of artists with disability - especially amateur artists with visual impairment, which are often ambiguous or hard to recognize (see D'Angiulli \& Maggi, 2003; Kennedy, 1993; Niestorowicz, 2017; Szubielska, 2018a; Szubielska, Niestorowicz, \& Marek, 2016; Szuman, 1967; Vinter, Bonin, \& Morgan, 2018), the cognitive mastering process may be a significant correlate of aesthetic appreciation. Through the awareness of creators with a disability, the cognitive mastering process may result in dissolving the ambiguity in what is perceived, increasing appreciation of the artwork. Simplistically, the more we feel we comprehend the art, the higher we evaluate it (Leder et al., 2004; Leder \& Nadal, 2014). Making sense of artwork might also cause the Aesthetic "Aha" effect - the experience of insight and subjective understanding of why the viewed artwork looks the way it does, causes an increase in aesthetic pleasure and results in higher appreciation 
of the artwork (see Muth, Ebert, Marković, \& Carbon, 2019; Muth \& Carbon, 2013; Muth, Pepperell, \& Carbon, 2013; Muth, Raab, \& Carbon, 2015, 2016). However, in previous studies on assessment of the works of disabled amateur artists (Niestorowicz, 2017; Szubielska et al., 2012), the declared understandability of artworks was not tested, so we do not know if aesthetic appreciation correlated more with the artwork's subjective understanding, taking into account both conditions, where information concerning the artists' disability was provided and where it was not.

Previously, the few available studies (Niestorowicz, 2017; Szubielska et al., 2012) on the effect of having information about the fact that the creators had a disability on subsequent aesthetic evaluations were conducted exclusively under laboratory conditions. Laboratory research on aesthetic experience lacks ecological validity and generalizability (see Carbon, 2017; Tschacher et al., 2012) and participants might not consider the reproductions of the artwork presented in a laboratory setting as artworks at all - which can influence aesthetic appraisals (see Pelowski et al., 2017). We decided to overcome these limitations of laboratory research on the effect of having awareness of authors' disability on aesthetic assessment, by conducting our study in an art gallery.

We consider our research to be a pilot study. The study aimed to determine if knowledge about creators with a disability affects both aesthetic appreciation and understanding of the works. Based on the attributional approach to creativity (Kasof, 1995) as well as the model of cognitive processing of aesthetic experiences (Leder et al., 2004; Leder \& Nadal, 2014), we expected that both aesthetic appreciation and subjective understanding of drawings would increase in the group informed about the fact that the authors are people with blindness in contrast to the uninformed group. Moreover, we predicted that the correlation between aesthetic appreciation and the subjective understanding of the artwork would be stronger in observers who received information about the fact that the creators were blind in comparisonto those who lacked this information.

\section{METHOD}

\section{Participants}

Thirty students (15 females) aged 18 to 27 years $(M=21.82, S D=1.27)$ participated in the study. Given the limited duration of the exhibition, which we wanted to use for our research in the art gallery, we were restricted to studying a small group, which we knew would only allow us to detect large effects. Taking into account previous studies on bias in assessment with smaller sample sizes, using the $\mathrm{G}^{*}$ Power 3.1 open-source program we calculated the required sample size for independent two-sample $t$-test analyses $(a=.05,1-b=.90, N 2 / N 1=1$, one-tail) with an expected minimum effect size $=1.10$ 
(see Graham \& Dwyer, 1987; Landy \& Sigall, 1974; King, 1998), and we obtained a total sample size $N=30$.

All of our subjects were non-experts in the field of art - which was determined both on their initial declarations and the floor effect obtained in the Art Experience Questionnaire (see Chatterjee, Widick, Sternschein, Smith, \& Bromberger, 2010). It was important for us to control art experience because viewers' expertise differentiates perception and aesthetic evaluation (e.g., Belke et al., 2006).

\section{Materials and Procedure}

The study itself took place in the Galeria Labirynt gallery - one of the most influential contemporary art galleries in Poland, during the exhibition "The City That Can't Be Seen" ["Miasto, którego nie widać"] on display from December 19th, 2017 until February 28th, 2018. Although the exhibition presented both a picture book, photographs, sculptures and embossed drawings made by people with visual impairments (see Szubielska, 2018a; Szubielska, Pasternak, Wójtowicz, \& Szymańska, 2018), the subject of the study was the assessment of drawings only - because of their highest level of undetectability (see Figure 1; for more drawings examples see Szubielska, 2018a). Each artwork was accompanied by a label containing information about the author's name, the artwork's title, and technique used.
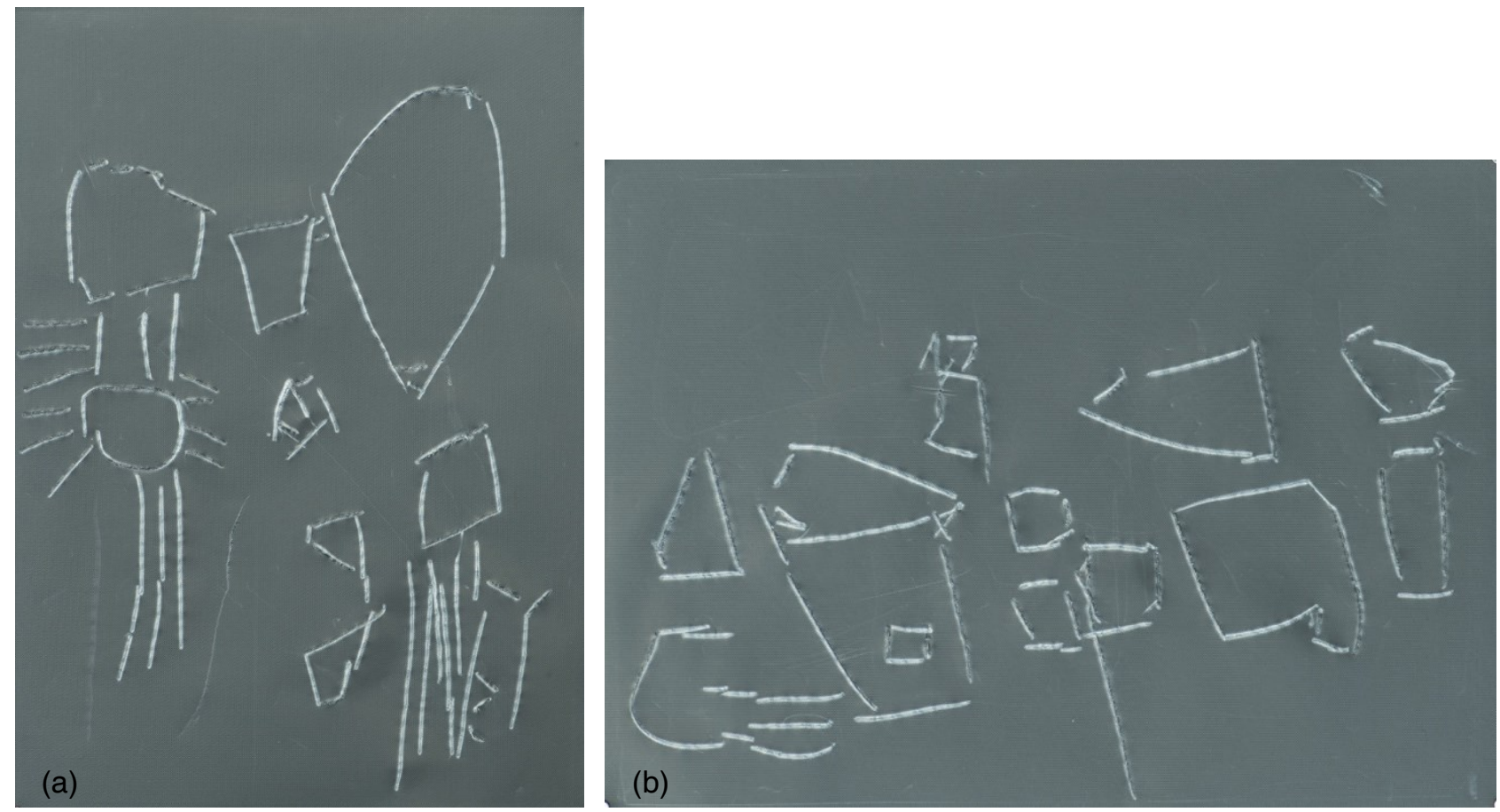

Figure 1. A Sample of Embossed Drawing from the Exhibition:

(a) depicting a Skyscraper, (b) depicting the Interior of the Theatre Building 
The procedure followed a between-subjects design. Participants were randomly assigned to two test conditions: experimental $(N=15)$ or control $(N=15)$ the distinction being based on the presence of information about the artists' sight disability. All participants - divided into groups of two, three people - were met at a given time at the entrance to the exhibition room, where only people from the experimental condition received the information about the artists' disability.

All participants could familiarise themselves with the works presented at the exhibition in any order and for an unlimited time. Then we asked them to evaluate twelve drawings in any order, reminding the participants from the experimental group that blind artists had created the drawings. The drawings were evaluated on seven-point scales of aesthetic experience selected to cover the ratings of Liking and Interest and Subjective Understanding ${ }^{1}$. All were Likert-type scales, where 1 stood for "very little" and 7 for "a lot". Ratings were made in the exhibition room. In the control condition, when all answers were marked, it was disclosed to the participants that people with blindness had created all the drawings presented at the exhibition ${ }^{2}$.

The study was approved by the Ethical Committee of the Institute of Psychology of The John Paul II Catholic University of Lublin and complied with the ethical standards of the Helsinki convention.

\section{RESULTS}

A reliability analysis indicated that the two scales assessing Interest and Liking were highly correlated $(\alpha=.98)$ and therefore, they were averaged into a single measure of Aesthetics appreciation (for similar practice see Mastandrea \& Crano, 2019; Smith \& Newman, 2014).

So, for further analysis, we took from each subject the two averaged results of their assessment of drawings in terms of Aesthetic appreciation and subjective Understanding (see Figure 2 \& Table 1).

\footnotetext{
${ }^{1}$ We also measured the affective experience on arousal and valance scales, but in this study we do not analyse these dimensions, treating them as buffer questions.

${ }^{2}$ Which often caused spontaneous comments from the participants like If I knew they were the artworks of blind people, I would rate them higher.
} 

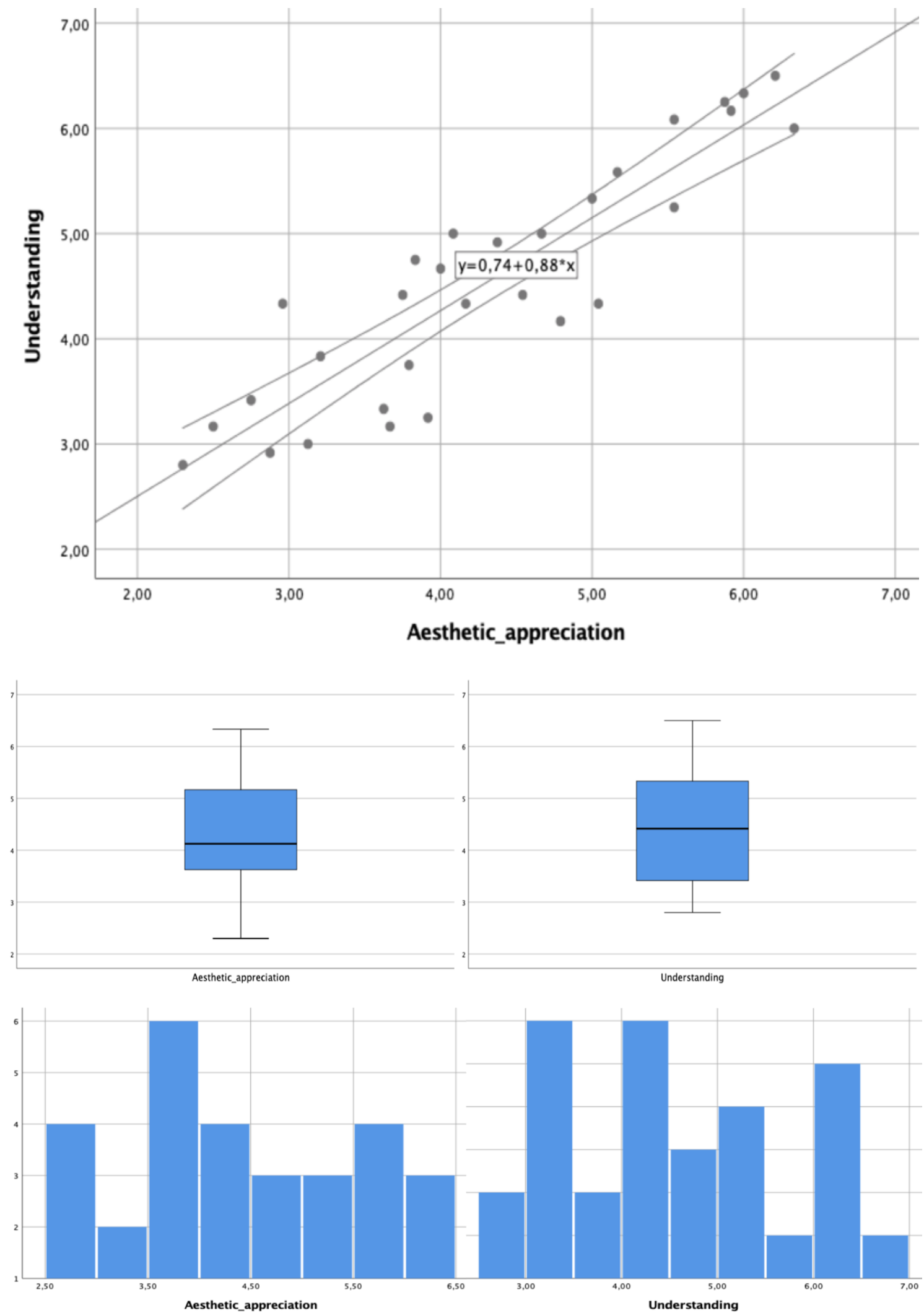

Figure 2. Scatter Plot with a linear regression line and a $95 \% \mathrm{Cl}$ (on the top), Box Charts (in between), and Histograms (at the bottom) of subjective Understanding and Aesthetic appreciation $(N=30)$ 
For the whole group of subjects, mean scores of Aesthetic appreciation and subjective Understanding were positively correlated. Table 1 shows the descriptive statistics and Pearson's $r$ value for the two variables.

\section{Table 1}

Descriptives Statistics and Pearson's $r$ Value for Study Variables: subjective Understanding (subjec. Understan.), Aesthetic appreciation (Aesthet. Appreciat.) $(N=30)$

\begin{tabular}{lllll}
\hline & M & SD & subjec. Understan. & Aesthet. Appreciat. \\
\hline subjec. Understan. & 4.55 & 1.14 & 1 & $.90^{* *}$ \\
Aesthet. Appreciat. & 4.32 & 1.16 & & 1 \\
\hline
\end{tabular}

${ }^{* *} \mathrm{p}<.010$

We used two separate two-sample independent $t$-tests with Bonferroni correction for multiple comparisons to analyse the effect of the presence of information that the creators were people with blindness on Aesthetic appreciation and subjective Understanding. We also calculated two measures of effect sizes: $d$ Cohen test and the Hedges's $g$ test with a correction for sample size (see Lakens, 2013).

The presence of information that the creators were people with a disability had a considerable impact on both: the Aesthetic appreciation $\left[t(28)=-3.58, p_{\text {corrected }}=.002\right.$ $(95 \% \mathrm{Cl}$ for means differences: $-2.13,-.58$; post-hoc power $=.97), d$ Cohen $=1.30(95 \%$ $\mathrm{Cl}$ for $d$ Cohen $=.50,2.08)$, Hedges's $g=1.26]$ and the subjective Understanding $[t(28)=$ $-5.11, p_{\text {corrected }}<.001$ (95\% Cl for means differences: $-2.18,-.94$; post-hoc power $=.99$ ), $d$ Cohen $=1.87(95 \% \mathrm{Cl}$ for $d$ Cohen $=.99,2.72)$, Hedges's $g=1.81]$.

Informed participants appreciated the drawings more $(M=4.96, S D=1.13)$ and rated them as more understandable $(M=5.33, S D=0.92)$ in comparison to the observers who did not know about the fact that the drawings were created by artists with visual disability $\left(M_{\text {appreciat. }}=3.61, S D_{\text {appreciat. }}=0.94 ; M_{\text {understand. }}=3.75, S D_{\text {understand. }}=0.77\right)$ (see Figure 3$)$.

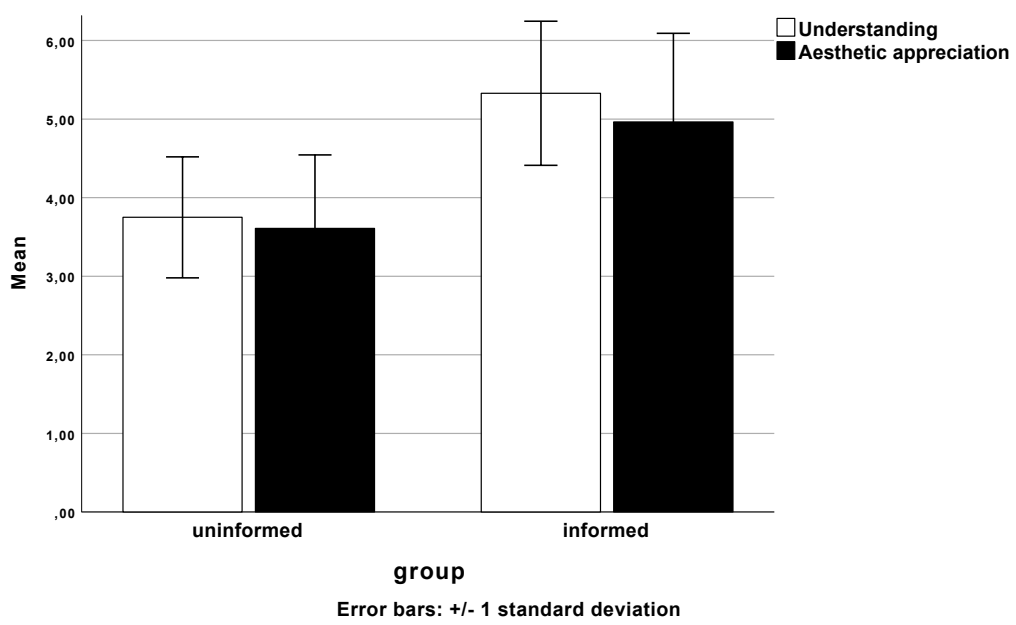

Figure 3. Bar Chart with mean subjective Understanding and Aesthetic appreciation of Drawings in informed and uninformed Groups about the fact that Persons 
Pearson's $r$ coefficients showed that the drawings' Aesthetic appreciation was positively correlated with their subjective Understanding both in the group of informed participants $(r=.93, p<.001)$ and among the unaware subjects $(r=.75, p=.001)$. Fisher's $z$ test, was used to measure the difference between the two correlations, and showed that the correlation between Aesthetic appreciation and subjective Understanding was stronger in the informed group than in the uninformed group $(z=1.68, p=0.047)$; the effect size for this difference was medium (Cohen's $q=.69$ ).

\section{DISCUSSION}

Our results showed that having information about the artworks' authors influenced aesthetic appreciation and is consistent with the results of previous empirical aesthetic research, showing - once again - that contextual information changes the reception of art (e.g., Cleeremans et al., 2016; Gerger \& Leder, 2015; Jucker et al., 2014; Leder et al., 2006; Mastandrea \& Crano, 2019; Millis, 2001; Russell, 2003; Russell \& Milne, 1997; Smith et al., 2006; Smith \& Newman, 2014; Specht, 2010; Swami, 2013; Szubielska, 2018b; Szubielska, Ratomska, et al., 2018; Szubielska, Wójtowicz, et al., 2018, Szubielska et al., 2019). More importantly, in our study we manipulated specific information about the impairment of the author of artworks, measuring not only aesthetic appreciation (as Niestorowicz, 2017; Szubielska et al., 2012), but also the declared subjective understanding of the works of art, and our respondents rated the real products of the work of people with blindness in the art gallery context.

We showed that the information that persons with blindness were the authors of the embossed drawings enhanced both their appreciation and subjective understanding. Moreover, the correlation between subjective understanding and aesthetic appreciation was significantly higher in the group who had been informed that the creators were people with a disability in comparison to a group of subjects who were unaware of this. This pattern of results can be explained by both the attributional approach to creativity (Kasof, 1995) and a cognitive mastering approach (Leder et al., 2004; Leder \& Nadal, 2014).

Based on the attributional approach to creativity (Kasof, 1995), our results indicate that having information about the disability of the artists influenced the reception of the creative work in the same way that other information concerning the author's gender or name have also been shown to do (see Lebuda \& Karwowski, 2013; Kaufman et al., 2010). According to the attributional approach, information about an author, that we associate with their work increases appreciation of all aspects related to creativity in comparison to a situation in which we have no information about the author of the work. 
Relating our results to a different theoretical perspective, the cognitive mastering stage of aesthetic evaluation model (Leder \& Nadal, 2014), we can conclude that the information about authors with a disability might allow the recipients to overcome the ambiguity of the perceived artwork. According to a model of aesthetic evaluation (Leder et al., 2004), people have a particular need for external cues that help them to interpret abstract art - exceptionally if it is ambiguous, and abstract art and the art of the blind have much in common (Szubielska, 2018a). That is why in the group informed about the authors' disability, in contrast to the uninformed group, the viewing of embossed drawings could give a self-rewarded experience of higher subjective understanding connected with higher aesthetic appreciation (see Leder \& Nadal, 2014).

The perception of people with disabilities in Poland is changing nowadays, becoming more positive and pro-integrative (see Czerwińska, 2011; Ostrowska, 1994; Palak, 2000; Sękowski, 1994; Wolińska, 2015). Stereotypes limiting individuals with disabilities to tragic dimensions that elicit regret and pity are concordant with a moral or medical model of disability (see Oliver, 1990). These models are now widely criticized by researchers dealing with disability studies (e.g., Symeonidou \& Loizou, 2018). However, in our research, when we informed previously incognizant subjects about the fact that the authors were blind, the subjects were moved. Sometimes they were shocked, but most of the time, they felt guilty and repeated the phrase contained in the title: "If I knew they were the expression of creativity in blind people, I would rate them higher." The issue of attitudes towards individuals with disabilities and aesthetic appreciation requires further research, in which attitudes towards such people might be controlled, using indirect methods of measurement (see Antonak \& Livneh, 1995; Fisher, 1993). Unfortunately, attitudes towards blindness were not controlled in the current study.

Our study in the art gallery was a pilot study. We knew that we were restricted to examining a relatively small sample because we were unable to recruit more participants, who were inexperienced gallery visitors, in the given time, in view of the opening hours of the temporary exhibition (the exhibition started just before Christmas and was on display for less than three months). Not having a large sample size, we were aware that our study would only reveal effects, if they were relatively large. We are aware of the fact that our relatively small sample size could have provoked exaggerated effect sizes (see Rochefort-Maranda, 2017). In previous bias evaluation studies, large effects were found, but only when small samples were tested (see Graham \& Dwyer, 1987; Landy \& Sigall, 1974; King, 1998; for a meta-analysis, see Malouff \& Thorsteinsson, 2016). 
Although testing aesthetic experience in a natural setting for viewing art might also be considered a strength of the study (see Carbon, 2017; Tschacher et al., 2012), it is on the other hand, fairly sporadic that the works of amateur artists with disabilities are exhibited at an art gallery. In follow-up studies, it would be worth presenting the work of artists with disabilities in a different physical context, and at the same time informing viewers that they are assessing artwork previously exhibited at a contemporary art gallery - in order to control the perception the stimuli as works of art (see Pelowski et al., 2017).

The goal of our research did not require professional assessment of aesthetic appreciation, but an assessment that might expose stereotypes about the artwork of people with a disability held by subjects in general (not by experts). Novice evaluators were therefore required for this particular study. We believe that expert knowledge protects observers, to some extent, against the use of stereotypes during the evaluation of artwork. According to a meta-analysis by Malouff and Thorsteinsson (2016), across all studies that used experienced graders, the weighted effect size $(g=.35)$ was lower than the effect size for inexperienced graders $(g=.46)$ (see also Graham \& Dwyer, 1987).

The results of our research may be significant for educational practice, especially for educators working in art galleries and museums. Our results showed that contextual information, which is passed on to non-expert visitors, changes not only aesthetic appreciation, but also subjective understanding of works of art. If viewers who typically do not visit galleries and museums receive tips that will help them give meaning to works of art, they will appreciate the art they view within the gallery more. Perhaps this might encourage them to visit future exhibitions and to more active participation in culture.

\section{Declaration of Conflicting Interests}

The authors declared no potential conflicts of interest concerning the research, the authorship, and the publication of this article.

\section{REFERENCES}

Antonak, R. F., \& Livneh, H. (1995). Direct and indirect methods to measure attitudes toward persons with disabilities, with an exegesis of the error-choice test method. Rehabilitation Psychology, 40(1), 3-24. https://doi.org/10.1037/0090-5550.40.1.3

Belke, B., Leder, H., \& Augustin, M. D. (2006). Mastering style - Effects of explicit stylerelated information, art knowledge and affective state on appreciation of abstract paintings. Psychology Science, 48, 115-34.

Bock, R. D. (1975). Multivariate statistical methods in behavioural research. New York: McGraw-Hill.

Carbon, C.-C. (2017). Art perception in the museum: How we spend time and space in art exhibitions. i-Perception, 8(1), 1-15. https://doi.org/10.1177/2041669517694184 
Chatterjee, A., Widick, P., Sternschein, R., Smith, W. B., II, \& Bromberger, B. (2010). The assessment of art attributes. Empirical Studies of the Arts, 28, 207-222. https://doi.org/10.2190/EM.28.2.f

Cleeremans, A., Ginsburgh, V., Klein, O., \& Noury, A. (2016). What's in a name? The effect of an artist's name on aesthetic judgments. Empirical Studies of the Arts, 34(1), 126-139. https://doi.org/10.1177/0276237415621197

Czerwińska, K. (2011). Osoby niewidome według dzieci w wieku wczesnoszkolnym [Blind people according to children in early school age]. Niepełnosprawność i Rehabilitacja, 1(1), 42-54.

D'Angiulli, A., \& Maggi, S. (2003). Development of drawing abilities in a distinct population: Depiction of perceptual principles by three children with congenital total blindness. International Journal of Behavioral Development, 27, 193-200. https://doi.org/ $10.1080 / 01650250244000191$

Fisher, R. J. (1993). Social desirability bias and the validity of indirect questioning, Journal of Consumer Research, 20(2), 303-315. https://doi.org/10.1086/209351

Gerger, G., \& Leder, H. (2015). Titles change the aesthetic appreciations of paintings. Frontiers in Human Neuroscience, 9, 464. https://doi.org/10.3389/fnhum.2015.00464

Graham, S., \& Dwyer, A. (1987). Effects of the learning disability label, quality of writing performance, and examiner's level of expertise on the evaluation of written products. Journal of Learning Disabilities, 20, 317-318.

Jucker, J.-L., Barrett, J. L., \& Wlodarski, R. (2014). “I just don’t get it”: Perceived artists' intentions affect art evaluations. Empirical Studies of the Arts, 32(2), 149-182. https:// doi.org/10.2190/EM.32.2.c

Kasof, J. (1995). Explaining creativity: The attributional perspective. Creativity research journal, 8(4), 311-366. https://doi.org/10.1207/s15326934crj0804_1

Kaufman, J. C., Baer, J., Agars, M. D., \& Loomis, D. (2010). Creativity stereotypes and the consensual assessment technique. Creativity Research Journal, 22(2), 200-205

Kennedy, J. M. (1993). Drawing and the blind: Pictures to touch. New Haven, CT: Yale University Press.

King, J. L. (1998). The effects of gender bias and errors in essay grading. Educational Research Quarterly, 22, 13-25.

Lakens, D. (2013). Calculating and reporting effect sizes to facilitate cumulative science: a practical primer for t-tests and ANOVAs. Frontiers in psychology, 4, 863.

Landy, D., \& Sigall, H. (1974). Beauty is talent: Task evaluation as a function of the performer's physical attractiveness. Journal of Personality and Social Psychology, 29, 299-304. doi: 10.1037/h0036018 
Lebuda, I., \& Karwowski, M. (2013). Tell me your name and I'll tell you how creative your work is: Author's name and gender as factors influencing assessment of products' creativity in four different domains. Creativity Research Journal, 25(1), 137-142. https:// doi.org/10.1080/10400419.2013.752297

Leder, H., Belke, B., Oeberst, A., \& Augustin, D. (2004). A model of aesthetic appreciation and aesthetic judgments. British Journal of Psychology, 95, 489-508. https:// doi.org/10.1348/0007126042369811

Leder, H., Carbon, C.-C., \& Ripsas, A.-L. (2006). Entitling art: Influence of title information on subjective understanding and appreciation of paintings. Acta Psychologica, 121(2), 176-198. https://doi.org/10.1016/j.actpsy.2005.08.005

Leder, H., \& Nadal, M. (2014). Ten years of a model of aesthetic appreciation and aesthetic judgments: The aesthetic episode-Developments and challenges in empirical aesthetics. British Journal of Psychology, 105(4), 443-464. https://doi.org/10.1111/ bjop.12084

Lundy, D. E. (2016). Decontaminating taste: Minimizing nonaesthetic biases in aesthetic appraisal. Review of Arts and Humanities, 5, 8-26.

Malouff, J. M., \& Thorsteinsson, E. B. (2016). Bias in grading: A meta-analysis of experimental research findings. Australian Journal of Education, 60(3), 245-256.

Mastandrea, S., \& Crano, W. D. (2019). Peripheral factors affecting the evaluation of artworks. Empirical Studies of the Arts, 37(1), 82-91. https://doi.org/10.1177/027623 7418790916

Millis, K. (2001). Making meaning brings pleasure: The influence of titles on aesthetic experiences. Emotion, 1(3), 320-329. https://doi.org/10.1037/1528-3542.1.3.320

Muth, C., \& Carbon, C.-C. (2013). The Aesthetic Aha: On the pleasure of having insights into Gestalt. Acta Psychologica 144(1), 25-30. https://doi.org/10.1016/j.actpsy. 2013.05.001

Muth, C., Ebert, S., Marković, S., \& Carbon, C.-C. (2019). “Aha”ptics: Enjoying an Aesthetic Aha During Haptic Exploration. Perception, 48(1), 3-25. https://doi.org/10.1177/ 0301006618818014

Muth, C., Pepperell, R., \& Carbon, C.-C. (2013). Give me Gestalt! Preference for cubist artworks revealing high detectability of objects. Leonardo, 46(5), 488-489. https:// doi.org/10.1162/LEON_a_00649

Muth, C., Raab, M. H., \& Carbon, C.-C. (2015). The stream of experience when watching artistic movies. Dynamic aesthetic effects revealed by the Continuous Evaluation Procedure (CEP). Frontiers in Psychology, 6:365. https://doi.org/10.3389/fpsyg.2015.00365 
Muth, C., Raab, M. H., \& Carbon, C.-C. (2016). Semantic stability is more pleasurable in unstable episodic contexts. On the relevance of perceptual challenge in art appreciation. Frontiers in Human Neuroscience, 10,43. https://doi.org/10.3389/fnhum.2016.00043

Niestorowicz, E. (2017). The world in the mind and sculpture of deafblind people. Newcastle upon Tyne: Cambridge Scholars Publishing.

Oliver, M. (1990). The politics of disablement. London: Mcmillan Press. https:// doi.org/10.1007/978-1-349-20895-1

Ostrowska, A. (1994). Niepełnosprawni w społeczeństwie. Postawy społeczeństwa polskiego wobec ludzi niepełnosprawnych [Disabled in society. Attitudes of Polish society towards people with disabilities]. Warsaw: Wydawnictwo Instytutu Filozofii i Socjologii PAN. Palak, Z. (2000). Uczniowie niewidomi i słabowidzący w szkołach ogólnodostępnych [Blind and visually impaired students in public schools]. Lublin: UMCS Publishing House.

Pelowski, M., Gerger, G., Chetouani, Y., Markey, P. S., \& Leder, H. (2017). But is it really art? The classification of laboratory-presented images as "art"/"not art" and correlations with appraisal and viewer interpersonal differences. Frontiers in Psychology, 8, 1729. https://doi.org/10.3389/fpsyg.2017.01729

Rochefort-Maranda, G. (2017, December 21). Inflated Effect Sizes and Underpowered Tests: How the Severity Measure of Evidence is Affected by the Winner's Curse. Retrieved from http://philsci-archive.pitt.edu/14237/1/inflated_sev.pdf

Russell, P. A. (2003). Effort after meaning and the hedonic value of paintings. British Journal of Psychology, 94 (Pt 1), 99-110. https://doi.org/10.1348/000712603762842138

Russell, P. A., \& Milne, S. (1997). Meaningfulness and the hedonic value of paintings: Effects of titles. Empirical Studies of the Arts, 15(1), 61-73. https://doi.org/10.2190/EHT3HWVM-52CB-8QHJ

Sękowski, A. E. (1994). Psychospołeczne determinanty postaw wobec inwalidów [Psychosocial determinants of attitudes towards invalids]. Lublin: Wydawnictwo UMCS.

Smith, L. F., Bousquet, S. G., Chang, G., \& Smith, J. K. (2006). Effects of time and information on perception of art. Empirical Studies of the Arts, 24(2), 229-242. https:// doi.org/10.2190/DJM0-QBDW-03V7-BLRM

Smith, R. K., \& Newman, G. E. (2014). When multiple creators are worse than one: The bias toward single authors in the evaluation of art. Psychology of Aesthetics, Creativity, and the Arts, 8(3), 303-310. http://dx.doi.org/10.1037/a0036928

Specht, S. M. (2010). Artists' statements can influence perceptions of artwork. Empirical Studies of the Arts, 28(2), 193-206. https://doi.org/10.2190/EM.28.2.e 
Swami, V. (2013). Context matters: Investigating the impact of contextual information on aesthetic appreciation of paintings by Max Ernst and Pablo Picasso. Psychology of Aesthetics, Creativity, and the Arts, 7(3), 285-295. http://dx.doi.org/10.1037/a0030965

Symeonidou, S., \& Loizou, E. (2018). Disability studies as a framework to design disability awareness programs: no need for 'magic' to facilitate children's subjective understanding. Disability \& Society. https://doi.org/10.1080/09687599.2018.1488677

Szubielska, M. (2018a). People with sight impairment in the world of visual arts: does it make any sense? Disability \& Society, 33(9), 1533-1538. https://doi.org/10.1080/ 09687599.2018.1480261

Szubielska, M. (2018b). Wpływ zajęć edukacyjnych prowadzonych w galerii na odbiór abstrakcyjnej sztuki współczesnej przez uczniów młodszych klas szkoły podstawowej [The influence of educational workshops held in a gallery on the reception of abstract contemporary art by primary education students]. Przegląd Badań Edukacyjnych [Educational Studies Review], 26(1), 21-44. DOI: http://dx.doi.org/10.12775/PBE.2018.002 Szubielska, M., Bałaj, B., \& Fudali-Czyż, A. (2012). Estetyczny odbiór fotografii poprzez stereotyp umysłowej niepełnosprawności twórcy [Aesthetic evaluation of photographs through the stereotype of author with intellectual disability]. Psychologia Społeczna, 7, 372-378.

Szubielska, M., Imbir, K., \& Szymańska, A. (2019). The influence of the physical context and knowledge about artworks on the aesthetic experience of interactive installations. Manuscript under review.

Szubielska, M., Niestorowicz, E., Marek, B. (2016). Drawing without eyesight. Evidence from congenitally blind learners. Annals of Psychology, 19, 681-700. https://doi.org/10. 18290/rpsych.2016.19.4-2en

Szubielska, M., Pasternak, K., Wójtowicz, M., Szymańska, A. (2018). Evaluation of art of visually impaired people by children and adults. Interdyscyplinarne Konteksty Pedagogiki Specjalnej, 22, 161-177.

Szubielska, M., Ratomska, M., Wójtowicz, M., \& Szymańska, A. (2018). The effect of educational workshops in an art gallery on children's evaluation and interpretation of contemporary art. Empirical Studies of the Arts, 0276237418790917.

Szubielska, M., Wójtowicz, M., Szymańska, A., Ratomska, M., \& Sztorc, A. (2018). Zajęcia edukacyjne towarzyszące wystawie a odbiór sztuki współczesnej przez dzieci przedszkolne $i$ wczesnoszkolne [The impact of educational classes accompanying the exhibition on the reception of contemporary art by pre-school and early-school children]. EDUKACJA Quarterly, 145(2). 
Szuman, W. (1967). O dostępności rysunku dla dzieci niewidomych [On drawing availability for blind children]. Warsaw: Państwowe Zakłady Wydawnictw Szkolnych.

Tschacher, W., Kirchberg, V., van den Berg, K., Greenwood, S., Wintzerith, S., \& Tröndle, M. (2012). Physiological correlates of aesthetic perception of artworks in a museum. Psychology of Aesthctics, Crcativity, and the Arts, 6(1), 96-103. https://doi.org/10. 1037/a0023845

Vinter, A., Bonin, P., \& Morgan, P. (2018). The severity of the visual impairment and practice matter for drawing ability in children. Research in Developmental Disabilities, 78, 15-26. https://doi.org/10.1016/j.ridd.2018.04.027

Wolińska, J. (2015). Percepcja społeczna, stereotyp niepełnosprawności - perspektywa aktora i obserwatora [Social perception, the stereotype of disability - actor-observer perspective]. Annales Universitatis Mariae Curie-Skłodowska. Sectio J, PaedagogiaPsychologia, 28(1), 45-66.

Corresponding author at: Agnieszka Fudali-Czyż, PhD, The Department of Experimental Psychology, Perception \& Cognition Lab., The Institute of Psychology, Faculty of Social Sciences, The John Paul II Catholic University of Lublin, Al. Racławickie 14, 20-950 Lublin, Poland

E-mail: agnieszka.fudali.czyz@ gmail.com 